\title{
TOWARDS SUSTAINABLE CITIES IN CROATIA
}

\author{
MARINELA KRSTINIĆ NIŽIĆ, MAŠA TRINAJSTIĆ \& ZVONIMIRA ŠVERKO GRDIĆ \\ Faculty of Tourism and Hospitality Management, University of Rijeka, Croatia
}

\begin{abstract}
Among the goals of the 2030 Agenda for Sustainable Development are cities that provide social and economic progress for their inhabitants. Urban management and development face many challenges in the continuous creation of new jobs and prosperity without harming the environment and resources. Most cities in Croatia, especially in the coastal areas, are recognized as tourism destinations: tourism is the most important economic activity. The aim of this paper is to investigate, based on secondary available data, whether having tourism as a generator of the city's overall development is sufficient to make it an attractive place to live. In these times of intensive economic, sociological and cultural changes, tourism destination management needs to recognize and to define a suitable and feasible model, methodology and the means of implementing urban destination development strategy. The mere notion of a tourism destination implies the integral management of all key stakeholders. Faced with negative demographic processes, the underdevelopment of the urban settlements network, with its function and economy, we conclude that national policies need to give special attention to those urban areas that lag behind the national average. Based on that analysis and the conclusions drawn from it, our paper suggests a model of a sustainable transitional city that is economically independent, and which is an attractive place not only for visiting tourists, but also for its residents throughout the year. Keywords: cities, Croatia, tourism development, regional development, destination management, sustainability.
\end{abstract}

\section{INTRODUCTION}

Cities are the greenhouses for ideas; the centers of commerce, culture and science; and the drivers of economic and social development [1]. Cities have enabled people to achieve social and economic advancement [2]; however, there are many challenges in the management and development of today's smart cities, in order to have them continue generating new jobs and prosperity, without concerns regarding land and resources [3]. Common urban challenges include: traffic congestion, high energy expenditures, inadequate waste management, lack of resources to provide basic services, lack of adequate housing, and infrastructure issues [4]. These challenges can be overcome in a manner that will enable further improvement and growth, by improving resource management, as well as reducing pollution and poverty [5]. Since the beginning of the 21 st century, the criteria for having a sustainable city or a city suitable for human living have become based on having a healthy environment, social and cultural sustainability, an efficient infrastructure, good communication and dialogue among all stakeholders participating in decision-making, and by encouraging innovation and creativity regarding the framework for sustainable development [6], [7]. That is why today, the issue of raising awareness and knowledge on sustainable development can be equated to the issue of our civilization's survival.

As the topic of this paper is exceptionally broad, the paper simply provides an overview of the particular elements of sustainable development within the example of analyzed cities in Croatia. Most cities in Croatia, especially in the coastal area, are recognized as tourism destinations: tourism is their most important economic activity; therefore, the aim of this paper is to investigate, based on secondary available data, whether tourism as a generator of a city's overall development is sufficient to make it an attractive place to live.

In times of intensive economic, sociological and cultural changes, tourism destination management needs to recognize and define a suitable and feasible model, methodology and 
the means of implementation of an urban destination development strategy. In this paper, we propose two basic hypotheses using the example of cities in Croatia:

H1: Cities that develop tourism show a greater degree of economic sustainability. $\mathrm{H} 2$ : Tourist destination cities with greater amounts of tourist arrivals also record a lower population outflow and a higher population inflow, compared to cities that do not develop tourism.

Development as a socio-economic category is a multidimensional and dynamic process: it is sometimes difficult to make a distinction between the subject and the object of development. There is no universal definition of development, so therefore there is also no singular international standard for measuring and monitoring it. In the context of city development, tourism implies there are total socio-economic changes sparked by planned and targeted public policies, with the aim of shifting the current state towards the desired state.

For the purpose of this paper, we used various scientific methods: the desk research method, where relevant data was gathered from scientific and expert literature, and from publications with national statistics. The discussion and conclusions on the need to implement the sustainable transitional city model were drawn by applying the analysis and synthesis method.

The paper is organized as follows: After the introduction, the second section describes the available literature. The third section describes the research methodology and analysis. The fourth section presents the research results and the discussion, and the final section provides the conclusions. The final section also details the limitations of this research, and provides guidelines for future research.

\section{LITERATURE REVIEW}

The issue of sustainable development of Croatian cities has intensified over the recent period; and is connected with demographic trends, geographical features and economic activities within cities [8]-[10]. While cities generate many problems, they also need to have these be resolved within cities. Additionally, urban issues cannot be fully separated from regional issues. Cities greatly depend on natural resources, and the flow of natural resources shows the interdependence of economic and demographic changes.

City management faces many challenges in situations when human, technical and financial resources are limited [11], [12]. Urban policies have to be based on an integral approach to management, focused on intersectoral communication and cooperation; while monitoring and evaluation of the success of city policies should also be fundamental [13]. In such a framework, a system with various indicators becomes essential. Criticism regarding the methods of developing indicators primarily aims at developing indicators that should encompass all aspects of development, including environmental, economic, social, technological, etc. [14]. Today, most authors agree that it is not possible to define one single indicator which can cover all dimensions [15]-[17].

This paper takes into consideration indicators such as the development index, general population mobility, and the amount of tourist arrivals, which can be taken as management tools. They should be able to assist city management in measuring the success of its policies. Furthermore, they should be included in formulating strategic development goals, and participation of these indicators in management should be a prerequisite.

Over time, the Driving Forces-Pressures-State-Impact-Response (DPSIR) approach was developed; and the standard European Environmental Agency indicator typology is based on it [18], [19]. This is shown in Fig. 1 [20]. 


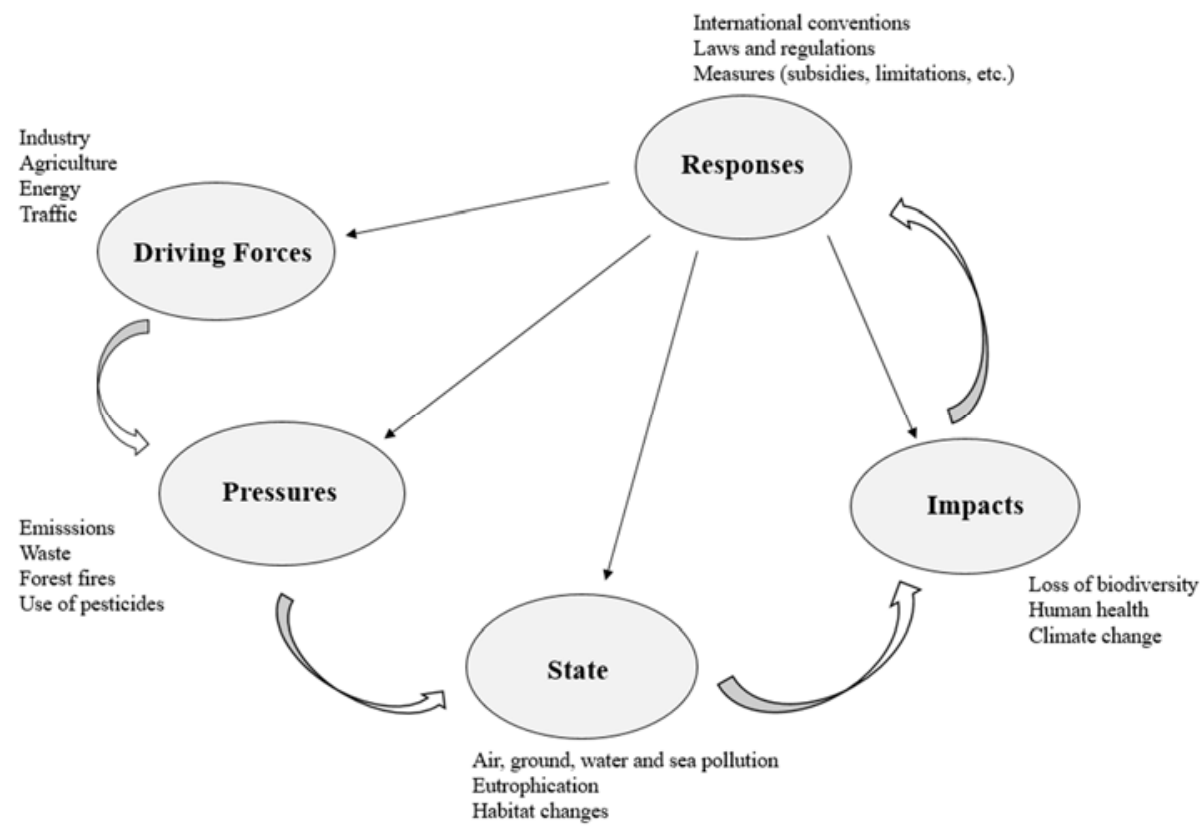

Figure 1: Relationship between driving forces, pressures, the state of various factors, the impact of certain changes, and the responses that occur [20].

According to the European Environmental Agency's standard indicator typology, indicators belong to one of the following categories:

- Driving Forces (D): fundamental driving forces of negative impact such as agriculture, industry, forestry, traffic, energy, tourism, etc.

- Pressures (P): the consequences of the activities of driving forces, such as: increases in fertilizer concentration and its components in the ground, air, water, etc.

- State (S): the current environmental state, i.e., the deterioration of air quality, soil, water, etc.

- Impact (I): the consequences of pressures such as the eutrophication of coastal areas, fragmentation, loss of biodiversity, etc.

- Response (R): measures and instruments which the society/state plans and implements with the goal of improving the state of a specific field, from legislative to financial and other measures [20].

The authors of this paper aim to prove that tourism, in addition to its negative impact on the environment, has a positive impact on the economy of every country, as shown by many authors [21]-[23].

\section{RESEARCH METHODOLOGY: ANALYSIS OF THE STATE OF SUSTAINABLE CITIES IN CROATIA}

The future concept of sustainable development had become a discussion topic in Croatia, already back in the 1970s. After the 1972 conference in Stockholm, Croatia was among 
the first countries in Europe to enact the "Resolution on the protection of human environment in Croatia" [24].

Non-government environmental protection organizations were formed, and activities were focused on developing and raising individual and social awareness about the environment. Government organizations for the environment were founded, and the "Declaration on Environmental Protection" and the "National Environmental Protection Strategy" were introduced [25]. In the "Environmental Protection Act" enacted in November 2007 [26], the "Strategy for Sustainable Development of the Republic of Croatia" assumes a key role as a document with a long-term focus on shifting economic and social development, and on environmental protection, working towards the sustainable development of Croatia [27].

The Strategy for Sustainable Development of the Republic of Croatia focuses on eight key areas, which imply specific general goals. These are [27]:

- Population: to support population growth in Croatia;

- Environment and natural goods: preservation, protection and sustainable management of goods;

- Sustainable production and consumption: with a focus on vital, sustainable production and balanced consumption;

- Social cohesion and justice: achieving social and territorial cohesion and justice;

- Energy: achieving energy independence and increasing the efficiency of energy use;

- Public healthcare: strengthening public healthcare;

- Connecting Croatia: further development of connections both within Croatia and within the region; and

- Protection of the Adriatic Sea, coast and islands.

It is imperative that existing processes in those areas are shifted towards more sustainable behaviors. These are the eight essential challenges of sustainable development that are also the basis of strategic development for Croatia. Generally speaking, sustainable development policies have to be implemented within other sectors' policies, especially tourism. Sustainability has to be based on applying the best available knowledge and methods, the existing principles already in effect within the Croatian legal system, all while taking into consideration economic feasibility, public healthcare and well-being [28].

Taking care of the economic development of all parts of Croatia, and encouraging both the economic development and social well-being of citizens is a constitutional category. Evaluating the level of development of territorial units is key for regional planning and development policies, and it is a criterion that is paramount for allocating different structural funds and government aid [29].

The goal of regional development policies is to contribute to the economic growth and development of Croatia in accordance with the principles of sustainable development, by creating the conditions that will enable all parts of the country to increase in competitiveness and realize their developmental potential, as prescribed by the Regional Development Act of Croatia enacted in 2009 [30].

The Act prescribes that the evaluation process be conducted every five years, while the last evaluation and classification of units of local and regional self-government within Croatia that was based on the development index, was conducted at the end of 2013. However, the data used in this paper is based on calculations conducted in 2017 by the Center for Local Economic Development, founded by the Faculty of Economics and Business in the University of Rijeka. 
The development index is a composite indicator calculated as the weighted average of six socio-economic indicators that the authors consider appropriate to use for calculations [31]:

- $\quad$ average income per capita;

- average original income per capita;

- $\quad$ average unemployment rate;

- general population mobility;

- $\quad$ population level of education; and

- aging index.

Taking into account the significant differences in population, area, strength of the local economy and fiscal capacity among cities; we have only taken into consideration the relative indicators, because the use of absolute indicators like population size, employment rate and total income is not appropriate for comparing local and regional units of self-government.

Based on the development index, we analyzed 20 cities in Croatia, above and below the average development level (index $=100$ ). In addition to the development index, we also analyzed the number of tourist arrivals, and if the given city had a "Strategy for City Development" document, as a basis for future sustainable development.

\subsection{Cities in Croatia based on the development index value, above the Croatian average}

Table 1 ranks Croatian cities based on their development index in 2017 [31], [32]. Based on the index, the most developed city is the capital, Zagreb, which also recorded the largest number of tourist arrivals in 2017. The second on the list is Dubrovnik, which in addition to all the other cities listed, is located in Adriatic Croatia. The Croatian Bureau of Statistics (CBS) [32] determines the national classification of territorial units for statistical purposes. In August 2012, the European Commission accepted the proposed division of the Republic of Croatia into two NUTS 2 regions, namely Continental Croatia and Adriatic Croatia [33].

Table 1: Cities in Croatia based on the development index value above the Croatian average (index $>100$ ).

\begin{tabular}{|l|c|c|c|c|}
\hline City & $\begin{array}{c}\text { Development } \\
\text { index, 2017 }\end{array}$ & $\begin{array}{c}\text { Number of } \\
\text { tourist } \\
\text { arrivals, } \\
2017\end{array}$ & $\begin{array}{c}\text { General } \\
\text { population } \\
\text { mobility, } \\
2006-2016\end{array}$ & $\begin{array}{c}\text { Development } \\
\text { strategy } \\
\text { document, } \\
\text { yes/no }\end{array}$ \\
\hline Zagreb & 116.56 & $1,286,087$ & 103.10 & Yes \\
\hline Dubrovnik & 115.64 & $1,174,878$ & 103.72 & Yes \\
\hline Poreč & 113.99 & 550,656 & 105.81 & Yes \\
\hline Krk & 113.72 & 215,620 & 113.58 & Yes \\
\hline Rovinj & 113.24 & 625,665 & 101.71 & Yes \\
\hline Umag & 112.28 & 456,308 & 106.12 & Yes \\
\hline Hvar & 111.67 & 197,361 & 107.87 & Yes \\
\hline Opatija & 111.57 & 433,196 & 93.35 & Yes \\
\hline $\begin{array}{l}\text { Mali } \\
\text { Lošinj }\end{array}$ & 111.49 & 286,395 & 101.06 & Yes \\
\hline Cres & 111.39 & 122,616 & 101.12 & Yes \\
\hline
\end{tabular}


Table 1 presents the data for general population mobility from 2006-16, calculated as the ratio of the comparable number of citizens in the last available 10-year period. Generally speaking, population mobility is an indicator of the demographic component of the development index. It points to demographic tendencies in the area of particular territorial units and, in most cases, it can be interpreted as a reaction to economic shifts. This is why tourism is the leading (and mostly, the only) economic activity that results in an increase of population within the analyzed tourist destinations: it is how these cities display their sustainability. The only decline in population can be seen in Opatija, which is developing elite tourism, so the inhabitants are moving to neighboring municipalities because of increased real estate prices.

These cities can be deemed sustainable, because they possess and implement their city development strategies.

\subsection{Cities in Croatia based on a development index value below the Croatian average}

Table 2 shows cities with development issues [31], [32]. The analyzed cities are located mostly in the central and eastern parts of the country, along the border with Bosnia Herzegovina and Serbia. Most cities belong to continental Croatia; they are not developing economic activities, tourism included, so there is no data for tourism indicators. Based on the number of tourist arrivals, particular cities in Table 2 are developing tourism, so their population decline is lower (such as Trilj and Skradin), compared to the rest. Even though these cities have rich natural resources and a lot of potential, they are not being used enough to improve the quality of their inhabitants' lives.

Table 2: Cities in Croatia based on a development index value below the Croatian average (index $<100$ ).

\begin{tabular}{|l|c|c|c|c|}
\hline City & $\begin{array}{c}\text { Development } \\
\text { index 2017 }\end{array}$ & $\begin{array}{c}\text { Number } \\
\text { of tourist } \\
\text { arrivals } \\
2017\end{array}$ & $\begin{array}{c}\text { General } \\
\text { population } \\
\text { mobility } \\
2006-2016\end{array}$ & $\begin{array}{c}\text { Development } \\
\text { strategy } \\
\text { document, } \\
\text { yes/no }\end{array}$ \\
\hline Glina & 91.17 & $\mathrm{n} / \mathrm{a}$ & 69.83 & Yes \\
\hline $\begin{array}{l}\text { Hrvatska } \\
\text { Kostajnica }\end{array}$ & 94.13 & $\mathrm{n} / \mathrm{a}$ & 69.37 & Yes \\
\hline Skradin & 95.14 & 20,062 & 84.46 & Yes \\
\hline Slunj & 95.19 & 53,828 & 76.91 & Yes \\
\hline $\begin{array}{l}\text { Grubišno } \\
\text { Polje }\end{array}$ & 95.33 & $\mathrm{n} / \mathrm{a}$ & 82.82 & Yes \\
\hline Vrlika & 95.76 & 339 & 76.76 & No \\
\hline Pleternica & 95.84 & $\mathrm{n} / \mathrm{a}$ & 86.50 & Yes \\
\hline Ilok & 95.86 & 5,988 & 82.75 & Yes \\
\hline Trilj & 95.97 & 5,319 & 93.03 & Yes \\
\hline Knin & 96.66 & 1,519 & 76.01 & Yes \\
\hline
\end{tabular}

n/a: not applicable (note: for Glina there was no data)

These cities show a lower tendency towards sustainability, due to a noticeable decline in population, as well as lower level of development for tourism. It is positive that the cities have a prepared development strategy document (excep Vrlika), which means that they do 
have a vision of the direction in which they want to develop. As a city, Vrlika does have a defined strategy for broader regional development.

Based on the observed data, it can be seen that Croatia has significant regional differences. Even though the differences between Croatian cities and regions is great for the country, these differences are also a problem when it comes to regional development inequalities. Apart from natural geographic and socio-economic differences, there are also large differences in regional development. There are many causes of regional inequality [34]. They can be the result of geographic distances, social and economic changes, or a combination of those factors.

The effects of these issues reflect on social poverty, poorer school quality, high unemployment rates and inadequate infrastructure. The issue of the exceptional depopulation of underdeveloped areas, different educational structure and different levels of economic development can especially be seen at the local level. In addition to the issue of high unemployment rates and the shutting down of economic activities, the issues of having lower levels of educated citizens and the outflow of the young and educated people prevent the creation of new opportunities for the development in underdeveloped areas. A poor socio-economic situation results in lower fiscal capacities for them or units of local self-government (in Croatia, units of local self-government are cities and municipalities) and makes the populace dependent on government aid [35]. Accordingly, the Strategy for the Regional Development of the Republic of Croatia until the end of 2020 had identified strategic goals that are planned to be realized through following the Strategy plan.

The development index is a functional tool for implementing activities, programs and projects, as well as for monitoring their implementation in the context of achieving goals, especially for monitoring the strategic goal to "Increase of quality of life through sustainable territorial development." Raising the levels of knowledge and the abilities to increase quality of life, securing and improving the basic local and regional infrastructure, and supporting subsidized fields and fields with developmental specificities, should be priorities that are worked on systematically. Measures are required that encompass a host of activities, projects and programs within the areas of education, sports, quality of life improvement, affirmation of cultural identity, development of a civil society, development of both local and regional infrastructure in accordance with society's needs, and the sustainable use and valorization of the country's cultural and natural heritage, providing support in applying environmental protection and energy efficiency measures at the local and regional levels.

\section{DISCUSSION}

The results of our research provide insight into the state of sustainable development in cities across Croatia, by observing the fact that tourist arrivals do affect economic development, achieving sustainability, and consequently, population inflow. The more developed cities need to be the forerunners and examples to other cities about how to attract new citizens and how to keep existing citizens, based on the principles of sustainable development. Based on the available data, it can be concluded that out of the 10 most developed cities that we analyzed [36]-[40], all have current strategies set up for total city development, as well as tourism development strategies.

When looking at cities with development issues, it can be observed that some strategies were developed in collaboration with neighboring cities, which represents an example of positive cooperation; but what obviously is lacking is coordination between the responsible stakeholders, for enacting target activities and goals [41]-[46]. It is important to strive towards having all cities in Croatia be focused on achieving sustainable development, for 
them to apply the Strategy for Sustainable Development. This includes using all the available tools for achieving environmental protection, social justice and economic sustainability; regardless of size, development, capacities, and other regional specificities.

Cities have various domestic and international sources of funding at their disposal, for projects based on city sustainability. Some cities were unsuccessful in drawing funds, which resulted in a lack of human resources for preparing and implementing projects, a lack of funding for projects, as well as unresolved property-legal affairs (and more). Part of these obstacles can be overcome on the local level, by hiring new people or training existing public servants, modernizing the city administration, designing the necessary strategies and preparing project documentation in a timely manner. In order to achieve improvement, even in less developed cities, the recommendation is to implement a sustainable, transitional city model, which is economically independent and is attractive to citizens and tourists throughout the whole year.

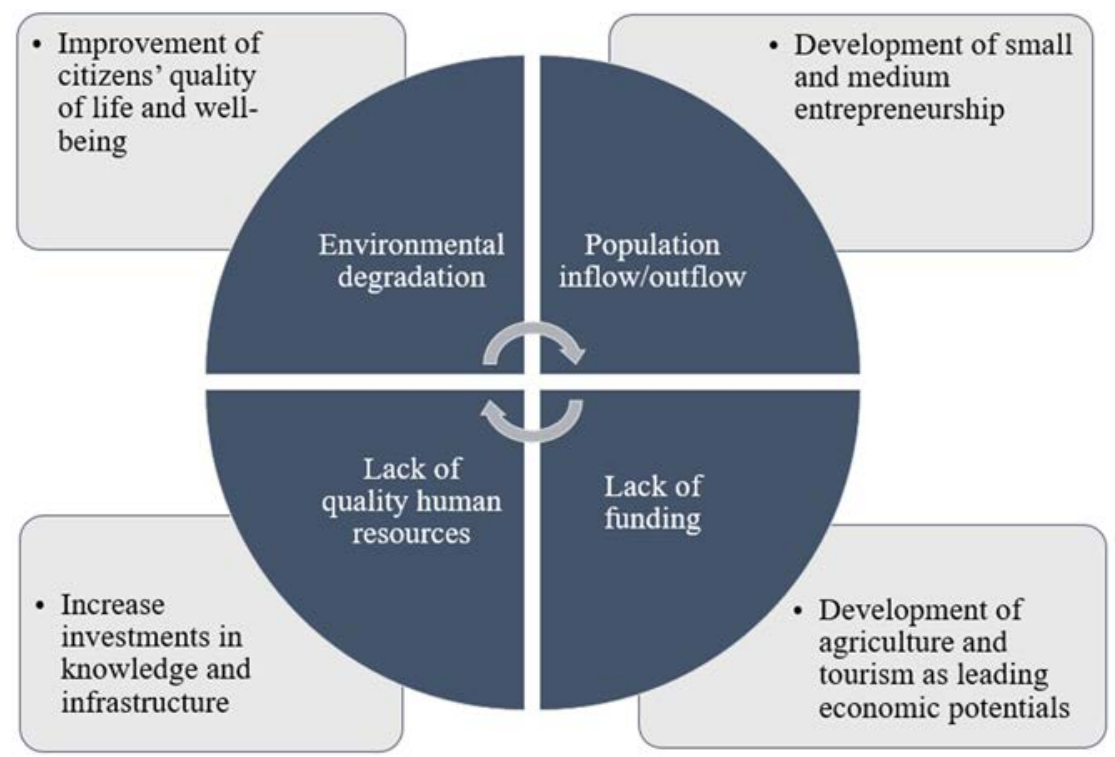

Figure 2: Goals and risks of sustainable cities in Croatia. (Source: Authors' proposal.)

The country can help with this process through simple adjustments in the legal framework, which would speed bureaucratic response time, create a positive image regarding the implementation of such projects, and create a positive environment that would enable simpler and cheaper access to project funding. Fig. 2 presents some of the issues that cities face. The biggest problem concerns the economy, i.e. the lack of jobs.

Cities need to invest more effort and work on improving the employment process, opening up new jobs on the labor market, and including jobs for people with disabilities and others with employability issues. It is necessary to improve the quality of services and life in general within each city, to improve infrastructure and public transportation, to open new jobs that can contribute to society's sustainability. Especially in the less developed cities, it is recommended that people work in agriculture. There is a constant need for raising awareness and for educating citizens about sustainable development, by supporting changes in the citizens' behavior. 


\section{CONCLUSIONS}

In order to meet the growing needs of citizens in tourist destinations and to solve problems related to the increases in urban populations, city managements should have to consider innovative approaches to achieving sustainable development. On the other hand, the analyzed cities which are not developing tourism as fast are recording a high population outflow, so attracting and keeping citizens presents an even greater challenge. Developing sustainable cities is the way to achieve an integrated approach to keeping citizens, but also environmental protection, because many components of natural ecosystems are intertwined with components of social, economic, cultural and political urban systems, to form a singular system. It is therefore necessary to improve the efficiency of all aspects of a city's services, including public and communal services, which is essential for securing a higher degree of economic efficiency and consequently, securing a better life for the citizens, with (in general) lower expenses.

Each city represents a unique system, where different agents such as city management, communal companies, and citizens conduct many activities, and create complex interactions and interdependencies. Taking into consideration that tourism impacts the ecological and social context of a city, its priorities, as well as its history and specific features, it is necessary to implement strategic urban planning that can enable finding the optimal route towards the final goal: a sustainable city.

The hypotheses that tourism contributes to the implementation of the concept of sustainable development by facilitating economic growth and efficiency, and by enabling a better life for citizens can be confirmed. As drivers of economic development, cities have to be prepared to tackle urban challenges, in order to secure smart and sustainable growth.

Our paper uses the examples of 20 cities within the Republic of Croatia (the 10 most developed cities and 10 cities with development issues), according to the development index. These cities should recognize measures for sustainable development as the best and most appropriate solution for their citizens, for increasing their well-being. It is necessary to learn from the experiences of local and global examples. Strategic and long-term planning is paramount in order to achieve a sustainable future.

Croatia is one of the countries that overly drain the Earth's resources, which is why it is necessary to increase knowledge and the understanding of principles of sustainable development, in addition to building the skills required to implement them. The solution involves changing policies at the local, national and global levels; as well as changing citizens' habits. Furthermore, Croatia's development index points to a key issue of economic policies: regional development inequality. The consequences of this inequality are the population losses within the least developed cities, which creates a vicious circle where it is impossible to initiate sustainable development and growth. This uneven economic development of Croatian cities follows the limits of social justice, i.e. the limits of quality of life and meeting particular social standards.

In addition to meeting ecological and economic needs, the cities in Croatia need to take care of their citizens' social needs, as well. According to the cities' strategic documents, it is important to improve the quality of services and life in cities, improve infrastructure and public transportation, and open new jobs that can contribute to the society's sustainability. The primary goal for the cities is to increase the quality of life of its citizens, in order for the cities to evenly develop on their path towards sustainable development.

We can also conclude that it is important to continuously increase the levels of knowledge and understanding of the principles of sustainable development, while building the skills required to implement them. Croatian cities should be transformed in such a way that they become more efficient, more pleasant to live in and sustainable, both in the short and long 
term. Such a change requires active cooperation between citizens, city management and the economy. Citizens should be better informed, and awareness raised on the importance of the sustainable use and preservation of the environment and natural resources, which also includes encouraging people to change existing behavioral patterns. This means that the patterns for gaining sustainable production and consumption should be implemented on all levels: corporate, social and personal.

Finally, it is necessary to point out the limitations of this research, primarily the fact that the analysis only included specific indicators, and only the top 10 best and worst cities based on the development index. Our recommendation for further research is to make a comparison with similar cities across the European Union (EU), as well as to conduct primary research in the sense of polls or interviews with citizens or local decision-makers.

\section{ACKNOWLEDGEMENT}

This paper has been fully supported by the University of Rijeka, under the project number "uniri-drustv-18-212."

\section{REFERENCES}

[1] Richards, G. \& Palmer, R., Cultural Management and Urban Revitalisation, Elsevier, 2010.

[2] Klopp, M.J. \& Petretta, D., The urban sustainable development goal: Indicators, complexity and the politics of measuring cities. Cities, 63, pp. 92-97, 2017.

[3] Yigitcanlar, T. \& Kamruzzaman, M., Does smart city policy lead to sustainability of cities? Land Use Policy, 73, pp. 49-58, 2018.

[4] Chandan, S. \& Kumar, A., Challenges for urban conservation of core area in pilgrim cities of India. Journal of Urban Management, 2019.

[5] United Nations (UN), 2030 Agenda for Sustainable Development. www.un.org/sustainabledevelopment/development-agenda/. Accessed on: 18 Jun. 2019.

[6] United Nations (UN), Sustainable cities: Why they matter? www.un.org/sustainabledevelopment/wp-content/uploads/2018/09/Goal-11.pdf. Accessed on: 19 Jun. 2019.

[7] Krstinić Nižić, M., Rudan, E. \& Trinajstić, M., The role of creative cities in regional development. Business Excellence, 13(1), pp. 35-55, 2019.

[8] Ribić, B., Voća, N. \& Ilakovac, B., Concept of sustainable waste management in the city of Zagreb: Towards the implementation of circular economy approach. Journal of the Air \& Waste Management Association, 67(2), pp. 241-259, 2017.

[9] Krstinić Nižić, M. \& Zubović, N., Urban ecology as the basis for urban living. Journal of the Polytechnic of Rijeka, 4(1), pp. 45-58, 2016. (In Croatian.)

[10] Mirkov, A., Urban social sustainability: A concept analysis. Sociology, 54(1), pp. 5570, 2012. (In Serbian.)

[11] McCann, P. \& Ortega-Argiles, R., Smart specialization, regional growth and applications to European Union cohesion policy. Regional Studies, 49(8), pp. 12911302, 2015.

[12] Boschma, R., Smart specialisation and regional innovation policy. Welsh Economic Review, 24, p. 17, 2016.

[13] Horvat, J. \& Pavković, M., Physical planning and programming agenda: Mapping and programming spatial potentials as a basis for integral development. A Scholarly Journal of Architecture and Urban Planning, 21(2/46), pp. 292-301, 2013. (In Croatian.) 
[14] Perišić, A. \& Wagner, V., Development index: Analysis of the basic instrument of Croatian regional policy. Financial Theory and Practice, 39(2), pp. 205-236, 2015.

[15] Garau, C. \& Pavan, V.M., Evaluating urban quality: Indicators and assessment tools for smart sustainable cities. Sustainability, 10(3), p. 575, 2018.

[16] Huovila, A., Bosch, P. \& Airaksinen, M., Comparative analysis of standardized indicators for smart sustainable cities: What indicators and standards to use and when? Cities, 89, pp. 141-153, 2019.

[17] Huenting, R. \& Reijnders, L., Broad sustainability contra sustainability: The proper construction of sustainability indicators. Ecological Economics, 50, pp. 249-260, 2004.

[18] Spangenberga, J.H. et al., Escaping the lock-in of continuous insecticide spraying in rice: Developing an integrated ecological and socio-political DPSIR analysis. Ecological Modelling, 295, pp. 188-195, 2015.

[19] European Environment Agency (EEA) website. www.eea.europa.eu/hr. Accessed on: 20 Jun. 2019.

[20] Agency for Environmental Protection, Report on the state of the environment. (In Croatian.)

www.sabor.hr/sites/default/files/uploads/sabor/2019-01-18/075522/04_Uvod.pdf. Accessed on: 18 Jun. 2019.

[21] Antonakakis, N., Dragouni, M. \& Filis, G., How strong is the linkage between tourism and economic growth in Europe? Economic Modelling, 44, pp. 142-155, 2015.

[22] Benur, A.M. \& Bramwell, B., Tourism product development and product diversification in destinations. Tourism Management, 50, pp. 213-224, 2015.

[23] Boes, K., Buhalis, D. \& Inversini, A., Smart tourism destinations: Ecosystems for tourism destination competitiveness. International Journal of Tourism Cities, 2 (2), pp. 108-124, 2016.

[24] Sustainable Development in Croatia, EU-Croatia Joint Consultative Committee, 2009. http://socijalno-partnerstvo.hr/wp-content/uploads/2013/04/Izvjesce-Odr\%C5\% BEivi-razvoj-u-RH-Pavic-Rogosic.pdf. Accessed on: 15 Jun. 2019.

[25] Drljača, M., Concept of sustainable development and management system. International Conference on Quality and Excellence, pp. 20-26, 2012. (In Croatian.)

[26] Zakon, Environmetal Protection Act. www.zakon.hr/z/194/Zakon-o-za\%C5\%A1titiokoli\%C5\%A1a. Accessed on: 15 Jun. 2019. (In Croatian.)

[27] Strategy for the sustainable development of the Republic of Croatia, https://narodnenovine.nn.hr/clanci/sluzbeni/full/2009 $03 \quad 30$ 658.html. Accessed on: 15 Jun. 2019. (In Croatian.)

[28] Lay, V., Sustainable development and leadership. Društvena istraživanja (Journal for General Social Issues), 16(6), pp. 1031-1053, 2007. (In Croatian.)

[29] Romao, J. \& Neuts, B., Territorial capital, smart tourism specialization and sustainable regional development: Experiences from Europe. Habitat International, pp. 1-11, 2017.

[30] Act on the regional development of the Republic of Croatia, 2009. https://narodnenovine.nn.hr/clanci/sluzbeni/2009_12_153_3746.html. Accessed on: 18 Jun. 2019.

[31] Centre for Local Economic Development (CLER), University of Rijeka, Faculty of Economics and Business website. https://cler.hr/. Accessed on: 10 Jun. 2019.

[32] Croatian Bureau of Statistics (CBS), www.dzs.hr/ (In Croatian.)

[33] National classification of spatial units for statistics, 2012 (NKPJS 2012). www.dzs.hr/hrv/important/nomen/NKPJS_2012/NKPJS\%202012_HR.pdf. 
[34] European Comission, EU regional and urban development, Regional policy. https://ec.europa.eu/regional_policy/en/atlas/croatia/. Accessed on: 18 Jun. 2019.

[35] Perišić, A., Multivariant classification of local and regional government units according to socio-economic development. Društvena Istraživanja (Journal for General Social Issues), 23(2), pp. 211-231, 2014.

[36] City of Zagreb development strategy for the period up to 2020. (In Croatian.) www.zagreb.hr/UserDocsImages/gu\%20za\%20strategijsko\%20planiranje/Razvojna \%20strategija\%20Grada\%20Zagreba_SGGZ_18-17.pdf. Accessed on: 15 Jun. 2019.

[37] Strategic plan of the City of Dubrovnik 2018-2020. (In Croatian.) www.dubrovnik.hr/uploads/20181206/STRATE\%C5\%A0KI_PLAN_GRADA DUBROVNIKA_2018._\%E2\%80\%93_2020._godine.pdf. Accessed on: 15 Jun. 2019.

[38] City of Poreč, Economic development strategy. (In Croatian.) www.porec.hr/download.aspx? $\mathrm{f}=\mathrm{d} \& \mathrm{fajl}=6098 /$ Strategija\%20gospodarskog\%20razvo ja\%20Grada\%20Poreca\%20-Parenzo_radna\%20verzija\%20za\%20e-konzultacije.pdf.

[39] Krk development strategy 2018-2022 (in Croatian), SmartCity. www.grad-krk.hr/ sites/default/files/files/02a_prijedlog_odluke_o_usvajanju_strategije_razvoja_pametn og_grada_krka.pdf. Accessed on: 16 Jun. 2019.

[40] Development strategy for the City of Rovinj for the period 2015-2020 (in Croatian). http://rovinjhr.lin53.host25.com/wp-content/uploads/2016/11/STRATEGIJAGRADA-ROVINJA-FINALNA-VERZIJA.pdf. Accessed on: 16 Jun. 2019.

[41] Development strategy of the City of Glina for the period 2009-2013 (in Croatian). www.grad-glina.hr/docs/strategijagg.pdf. Accessed on: 17 Jun. 2019.

[42] City of Hrvatska Kostajnica strategic development plan for 2018-2023 (in Croatian). www.hrvatska-kostajnica.hr/uploads/GHK_Strategija_finalno.pdf. Accessed on: 17 Jun. 2019.

[43] Development strategy of the City of Skradin for the period 2015-2020 (in Croatian). www.grad-skradin.hr/clanci/strategija-razvoja-grada-skradina-2015-2020/20.html. Accessed on: 18 Jun. 2019.

[44] Development strategy of the city of Ilok for the period 2016-2020 (in Croatian). http://ilok.hr/baza-podataka/natjecaji-nabava/uploads/Strategija_razvoja_ lipanj_2016.pdf. Accessed on: 18 Jun. 2019.

[45] City of Trilj and municipality of Otok overall development program (in Croatian). www.opcina-otok.hrstrategije/download/106_ed0f1cc5bc641a4ad204eded820255bc. Accessed on: 18 Jun. 2019.

[46] Development strategy of the City of Knin for the period 2018-2023 (in Croatian). www.knin.hr/wp-content/uploads/2018/02/Strategija-razvoja-Grada-Knina-20182023-za-javnu-raspravu09022018A.pdf. Accessed on: 18 Jun. 2019. 